\title{
A STUDY ON WATER QUALITY FROM LANGAT RIVER, SELANGOR
}

\author{
Alfarooq O. Basheer, Marlia M. Hanafiah*, Mahmood J. Abdulhasan \\ School of Environmental and Natural Resource Sciences, Faculty of Science and Technology, Universiti Kebangsaan \\ Malaysia,43600 Bangi, Selangor, Malaysia \\ *Corresponding author: mhmarlia@ukm.edu.my
}

This is an open access article distributed under the Creative Commons Attribution License, which permits unrestricted use, distribution, and reproduction in any medium, provided the original work is properly cited.

\section{ARTICLE DETAILS}

Article history:

Received 19 October 2017

Accepted 19 October 2017

Available online 25 October 2017

\section{Keywords:}

Water quality; water management; water pollution; water supply; Selangor

\section{ABSTRACT}

Langat River is one of the main sources of water supply for Selangor state. This study was conducted to determine the water quality status of Langat River in Selangor based on WQI and INWQS. Water sampling was conducted at ten stations for two seasons; dry season during February 2016 and wet season during November 2016. Parameters included in this study are temperature, pH, DO (Dissolved Oxygen), Conductivity, TSS (Total Suspended Soil), TDS (Total Dissolved Oxygen), BOD (Biochemical Oxygen demand) and Heavy metals. The laboratory analysis was carried out according to the HACH and APHA methods. This study found that the water quality of Langat River is classified in class III for both sampling times. Reduction in WQI value in the river was observed mainly due to human activities such as industrial and services building producing wastes. Based on results and statistical analysis, the values of $\mathrm{pH}$ COD, Conductivity, TSS and TDS in the study area were influenced by the nearby industrial constructions. In dry seasons, low volume and stagnant water could create entropic conditions in the river. Water quality which classified in class III were considered as slightly polluted. Langat River can be used as supply if only conventional treatment was done. Water quality which classified in class III were considered as slightly polluted. Langat River can be used as water supply if only conventional treatment is carried out.

\section{INTRODUCTION}

Rivers play a major role in assimilation or carrying off the municipal and industrial wastewater, runoff from agricultural land and other pollutant discharge. The municipal and industrial wastewater discharge constitutes the constant polluting source or sewage, whereas, the surface run-off is a seasonal phenomenon, largely affected by climate in the basin. Seasonal variations in precipitation, surface run-off, interflow, groundwater flow and pumped in and outflows have a strong effect on river discharge and subsequently on the concentration of pollutants in river water. However, quality of water is deteriorating all over the world in many ways. Anthropogenic activities are the main causes of water pollution. The end points of effluent discharged from industries are water bodies [1]. In Malaysia, the riverine ecosystem is of particular interest since river water provides about $98 \%$ of the country's water requirements [2]. Therefore, contamination of river and reservoir water poses a serious health risk. According to the Department of Environment (DOE), the biggest sources of industrial water pollution in Malaysia are food and beverage industries, chemical based industries, textiles, paper, palm oil and rubber processing industries $[3,4]$. Such rapid development of industries however has increased the water pollution level in Malaysia [5].

Langat River is one of the most important raw water resources for drinking water, recreation, industry, fishery and agriculture in Selangor State, Malaysia. The river flows from the highest peak of 1493 meter of Gunung Nuang across Langat Basin to Kuala Langat and land use activities along the river banks contribute to deterioration of river water quality. The sources of the Langat River pollution are identified as industrial discharge (58\%), domestic sewage from treatment plants $(28 \%)$, construction projects $(12 \%)$ and pig farming (2\%) [6]. A study from a research showed that major sources of surface water quality variations in Langat River come from industrial effluents, wastewater treatment plants, domestic and commercial areas [7].

It is also obvious that the Langat River ecosystem is under stress from the discharge of effluents particularly domestic sewage [8]. In 2006, the Department of Environment (DOE) Malaysia has announced Langat River as polluted river. This is due to industrialization taking place rapidly in area along the Langat River that lead to river pollution. There are houses and shops along a $20 \mathrm{~km}$ stretch from Cheras KM14.4 to the Langat River dam. Further down at KM17.6, there are workshops and light industrial factories along the main road. The drains from these premises lead to a larger drain and empty out into Langat River. Moreover, the sewage from these premises was not being channelled into any sewage treatment plant before the wastewater being released to Langat River. The villagers claimed that the Langat River at few kilometres downstream from the dam was polluted due to factories, warehouses and homes that been built along the river.
Water pollution also can result from natural runoff, dissolved chemicals in water that percolates thorough the soil and through land use activities, such as agricultural, mining, construction, industry, residential and businesses area. The time frame for the movement of some pollutants entering the water body is unpredictable depending on the features of particular pollutant. Excessive land application of manure can impair water quality by introducing pollutants including sediment and nutrients [9]. Since State of Selangor has undergoing rapid development, the population, also rising the human activities in utilizing the land along the river bank gives a great adverse impact on the river basin. Langat River in Selangor Malaysia has a potential for recreational uses especially for $60 \%$ of users in valley. River water is essential for residential use, industries, irrigation and numerous other activities [10]. The water quality of the Langat river basin, one of the most densely populated areas within the region, is significantly degraded due to human activities as well as urbanization. Attempt has been made by the Department of Environment, Selangor to resolve the problem of water pollution. The 'Sub-Group Activity' concept was implemented where water quality monitoring of various polluting sources was carried out in addition to law enforcement and river pollution education and awareness activities [8].

This study aims to determine the water quality status based on physical and chemical parameters in Langat River (i.e. conductivity, Ammoniacal Nitrogen, chemical oxygen demand (COD), Biochemical oxygen demand (BOD), Dissolved oxygen (DO), Total Suspended Solid (TSS), Total Dissolved Solid (TDS), pH) and to measure the heavy metals concentration in Langat River

\section{METHODOLOGY}

\subsection{Study Area and Water Sampling}

Langat River plays a crucial role in water supply, fishing, waste disposal, agriculture and industry. However, the river's catchment area has been subject to deforestation, intensification of agriculture, soil erosion, urbanization, and industrialization. As a result, water pollution and water shortages have now become a severe problem $[10,11]$. The study area of the Langat River is located between latitudes $2^{\circ} 58^{\prime} 48.6^{\prime \prime} \mathrm{N}$ and longitudes $101^{\circ} 47^{\prime} 07.1^{\prime \prime}$ E. Sampling stations in the study area were divided into ten stations based on different activities along the Langat River as shown in Figure 1 and description of each sampling station is given in Table 1. Sampling activities were conducted two times and 10 sampling sites (upstream, middle stream and downstream) were chosen. 


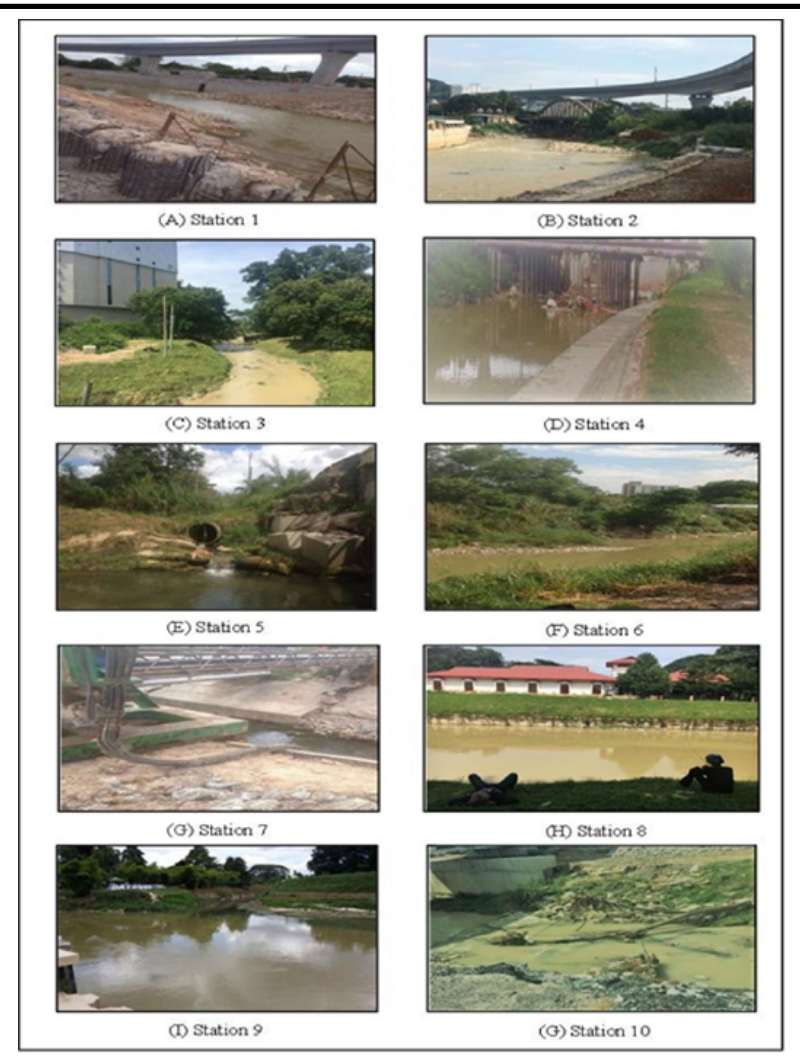

Figure 1: $(a-j)$. Location of the study area at Langat River

Table 1: Description of 10 sampling stations

\begin{tabular}{|c|c|}
\hline Stations & Area description \\
\hline Station 1 & This station closes to train (MRT) construction \\
\hline Station 2 & $\begin{array}{l}\text { This station closes to construction building \& train (MRT) } \\
\text { construction }\end{array}$ \\
\hline Station 3 & $\begin{array}{l}\text { This station closes to KPJ hospital \& train (MRT) } \\
\text { construction }\end{array}$ \\
\hline Station 4 & This station adjacent to restaurants and cafeterias \\
\hline Station 5 & This station closes to sewage \\
\hline Station 6 & This station closes to residential houses and constructions \\
\hline Station 7 & This station closes to generators and construction \\
\hline Station 8 & This station closes to fishing areas and restaurants \\
\hline Station 9 & This station closes to the park and fishing area \\
\hline Station 10 & $\begin{array}{l}\text { This station received waste from construction during } \\
\text { operation }\end{array}$ \\
\hline
\end{tabular}

\subsection{In-situ and Ex-Situ Analysis}

All sampling bottles were washed with distilled water prior analysis to ensure no impurities found in the bottle that can affect the water samples. Nine parameters were included to determine the quality of Langat River; $\mathrm{pH}$, conductivity, Total Dissolved Solids (TDS), Total Suspended Solids (TSS), Ammoniacal Nitrogen (NH3-N), Biochemical Oxygen Demand (BOD), Chemical Oxygen Demand (COD), Dissolved Oxygen (DO) and heavy metals. In-situ measurement of temperature, dissolved oxygen (DO), electrical conductivity, total dissolved solids (TDS) and $\mathrm{pH}$ were obtained using YSI Model 556 Multi probe system (MPS). This instrument was calibrated and cleaned before being used for the sampling [12].

Concentration of heavy metals, BOD, COD, TSS, and Ammoniacal Nitrogen were determined in the laboratory. The water samples for the parameters BOD, COD, heavy metals and Ammoniacal Nitrogen were stored in temporary ice box container before being transported to the laboratory for analysis. For BOD parameter, water samples were collected using dark glass bottles. Bottles were totally dipped into water with the lid on. The bottle mouth was directed downward in the water at a depth of $10-15 \mathrm{~cm}$ below the water surface. After all the bottles were filled with water sample and free from air bubbles, the bottle lids were closed. APHA (2005) method was used to measure the BOD5 days. At the end of the five-day period, the remaining dissolved oxygen was 20 measured. The relationship between oxygen that was consumed during the five days and the volume of the sample increment were then used to calculate the BOD5. The BOD5 was calculated as follows:
For parameters such a TSS, COD, heavy metals and Ammoniacal Nitrogen, the water samples were collected by using the High-Density Polyethylene (HDPE) bottles. COD was analysed in the laboratory using the reactor digestion method. The reactor was heated until the temperature reached $150{ }^{\circ} \mathrm{C} .2 \mathrm{ml}$ of water sample was added into the vials using clean volumetric pipet. The second vial was added with $2 \mathrm{ml}$ of deionized water. The vials were gently inverted to several times then, were placed in the reactor and heat for two hours. After that vials were cooled for about 20 min, the reading was obtained using HACH 2005.

Total Suspension Solid (TSS) was analysed using TSS Dried at $105{ }^{\circ} \mathrm{C}$ method (APHA 2005). Glass fibre filter paper Whatman with 0.45 um pore size and a diameter of $47 \mathrm{~mm}$ was filtered with deionizer water to ensure that no dissolved salts and impurities present. Then, the filter paper was dried at temperature of $105^{\circ} \mathrm{C}$ in the oven for two hours and weighed. Then, filter papers were cooled in desiccators before being weighed to obtain a balanced weight with temperature. Difference weight of filter paper before and after filtration was calculated to obtain the weight of suspended solids.

Total Suspended Solids $(\mathrm{mg} / \mathrm{L})=(\mathrm{A}-\mathrm{B}) \times 1000 /($ Sample volume, $\mathrm{mL})$ Where:

A: Weight of filter paper before filtration in $\mathrm{mg}$ $\mathrm{B}$ : Weight of filter paper after filtration in $\mathrm{mg}$

Ammoniacal Nitrogen was measured using Nesslerization method. This analysis uses the principle of colorimetric. A total of $25 \mathrm{ml}$ of water sample was filled into the measuring cylinder. $25 \mathrm{ml}$ of deionized water blank was filled into another measuring cylinder respectively. Next, 3 drops of mineral stabilizer and solution of polyvinyl alcohol dispersant were added to both of cylinders and shaken for mixing to get the perfect solution. Then, $1 \mathrm{ml}$ of Nessler reagent was added into each of measuring cylinder and shaken. Both of measuring cylinders were left 1 minute for the reaction to begin. Finally, each solution was poured into a round sample cell to be measured with $\mathrm{HACH}$ spectrophotometer and adjusted to 380 programs and $426 \mathrm{~nm}$ wavelengths.

Analysis of heavy metals was carried out using Inductively Coupled Plasma Mass Spectrometry (ICP-MS). $50 \mathrm{ml}$ of water sample was filtered with Whatman filter paper $(0.45 \mu \mathrm{m})$ using the vacuum filtration Kit. Water sample were filtered to avoid any interference in the reading of ICPMS due to the presence of any suspended material. The water samples were sent to the instrumentation laboratory in UKM to determine the concentration level of heavy metals presence in water.

\section{RESULTS AND DISCUSSION}

Figure 2 (a-h) shows the results for 10 sampling stations for parameters DO, pH, conductivity, TDS, BOD, COD, TSS and Ammoniacal Nitrogen (NH3$\mathrm{N})$. The average DO for 10 sampling stations was between $4.4 \mathrm{mg} / \mathrm{l}$ to 7.73 $\mathrm{mg} / \mathrm{l}$ with the average value of $6.2 \mathrm{mg} / \mathrm{l}$. The DO values were classified in class II according to the standard of the Water Quality Index (WQI). The $\mathrm{pH}$ values obtained was ranged from 5.91 to 6.79. Figure 2 also shows the average of conductivity values ranged from $238 \mu \mathrm{S} / \mathrm{cm}-270 \mu \mathrm{S} / \mathrm{cm}$. The average TDS values were ranged between $6.11 \mathrm{mg} / \mathrm{l}-10.6 \mathrm{mg} / \mathrm{l}$ with the average $8.35 \mathrm{mg} / \mathrm{l}$. The biochemical oxygen demand (BOD) for 10 sampling stations were recorded between $0.84 \mathrm{mg} / \mathrm{l}$ to $1.64 \mathrm{mg} / \mathrm{l}$, with the average value of BOD reading was $1.53 \mathrm{mg} / \mathrm{l}$. Chemical Oxygen Demand (COD) is the amount of oxygen required to oxidize organic and inorganic chemicals found in the water. The range of COD values were recorded between $2-16 \mathrm{mg} / \mathrm{l}$ (with average of $9 \mathrm{mg} / \mathrm{l}$ ). The total suspended solids (TSS) values are also shown in Figure 2, ranged between $0.0035 \mathrm{mg} / \mathrm{l} \mathrm{-}$ $0.008 \mathrm{mg} / \mathrm{l}$. Ammoniacal Nitrogen (NH3-N) obtained for 10 sampling stations were between $0.1 \mathrm{mg} / \mathrm{l}-0.3 \mathrm{mg} / \mathrm{l}$. with the average value of 0.24 $\mathrm{mg} / \mathrm{l}$ 


\section{CONCLUSION AND RECOMMENDATION}

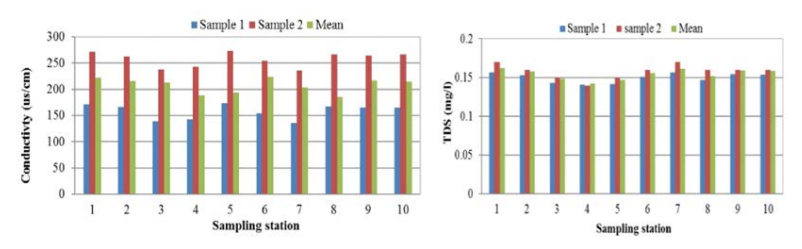

(c)

(d)

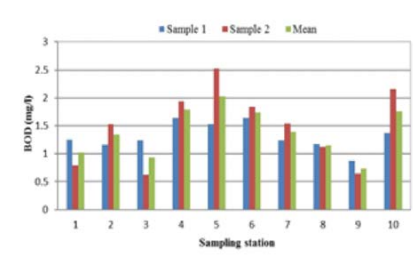

(e)

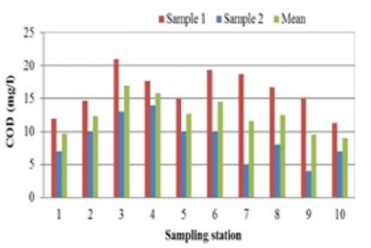

(f)

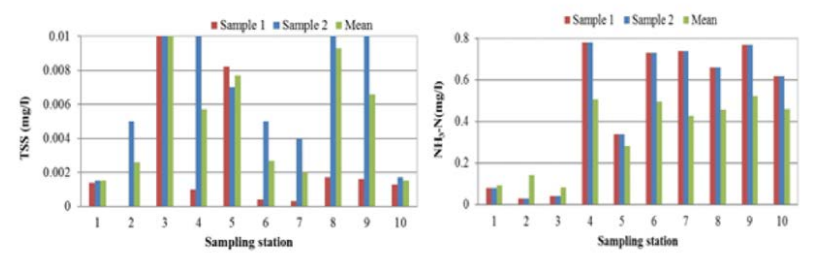

(g)

(h)

Figure 2: (a-h). Results for 10 sampling stations for parameters (a) DO, (b) $\mathrm{pH}$, (c) conductivity, (d) TDS, (e) BOD, (f) COD, (g) TSS, and h) Ammoniacal Nitrogen (NH3-N).

Based on the findings, Langat River was classified in class III based on the WQI classification [13]. The water quality at Langat River is highly affected by the surrounding human activities such as construction, manufacturing factories, sand mining and from domestic wastes. Frequent monitoring and assessment need to be conducted to update the status of water quality at Langat River. Table 2 shows the results for heavy metals. The average concentration for $\mathrm{Mn}, \mathrm{Zn}, \mathrm{Fe}$ and Cd were $0.07,0.02,0.59,0.0002 \mathrm{mg} / \mathrm{l}$, respectively. The presence of heavy metals in Langat River was mainly from the industrial and construction activities surrounding the area. The continuous deterioration of water quality in Langat River needs to be monitored due to the important of Langat River that is not only limited to supply clean water but also for other purposed [14]. It is crucial to evaluate the availability and demand of water resources at Langat River [15]. Implementation of the concept of Integrated Water Resources Management (IWRM) can serve as alternative to improve the status of Langat River.

Table 2: Mean values of heavy metals at 10 sampling stations

\begin{tabular}{|ccccc|}
\hline Station & $\begin{array}{c}\mathbf{M n} \\
\mathbf{m g} / \mathbf{L}\end{array}$ & $\begin{array}{c}\mathbf{Z n} \\
\mathbf{m g} / \mathbf{L}\end{array}$ & $\begin{array}{c}\mathbf{F e} \\
\mathbf{m g} / \mathbf{L}\end{array}$ & $\begin{array}{c}\mathbf{C d} \\
\mathbf{m g} / \mathbf{L}\end{array}$ \\
\hline 1 & 0.06 & 0.03 & 0.52 & 0.0002 \\
2 & 0.07 & 0.03 & 0.57 & 0.0001 \\
3 & 0.07 & 0.02 & 0.53 & 0.0003 \\
4 & 0.08 & 0.02 & 0.63 & 0.0001 \\
5 & 0.08 & 0.02 & 0.62 & 0.0003 \\
6 & 0.08 & 0.02 & 0.66 & 0.0001 \\
7 & 0.06 & 0.01 & 0.6 & 0.0001 \\
8 & 0.06 & 0.02 & 0.52 & 0.0002 \\
9 & 0.07 & 0.01 & 0.53 & 0.0001 \\
10 & 0.06 & 0.01 & 0.58 & 0.0002 \\
\hline
\end{tabular}

Water pollution due to various toxic solid wastes, effluents and emission are being discharged, resulting in an excessive amount of toxic and hazardous metals in local ground water. Due to discharge of untreated industrial effluents in the sewage channels, the ground water quality is deteriorated to great extent, therefore, availability of healthy, clean and good quality drinking water is a matter of great concern especially in the urban areas. Increasing population and uncertain climatic change will pose heavy demands on water quality in the future. Holistic approaches and integrated management principles will be necessary to develop sustainable water management and prevent catastrophes. Therefore, the sources of fresh water supply especially Langat River is needed to make sure it is clean for water supply and also well sustained from declining from the natural sources to be consumed by community within Langat watershed.

Therefore, it is very important to identify the pollutant sources through point source pollution based on the land use activities that took place around the Langat basin. Importantly, the non-point source pollutions are more concern than the point source solution due to difficulties to identify the sources specifically whereby the pollutants is hard to isolate and to control impurities entering the surface-waterbody. Thus, in order to make sure the Langat River is clean, the sources of pollutant discharge from the land use activities along the Langat River basin must be identified and controlled.

\section{ACKNOWLEDGEMENT}

Marlia Mohd Hanafiah was financed by research grants: ST-2016-015 and DIP-2017-006.

\section{REFERENCES}

[1] Ravichanddran, M., and Ganesan, J. 2012. Ethics and sustainability: a review of water policyand management. American Journal of Applied Sciences, 9 (1), 24-31.

[2] Azhar, M. G. 2000. Managing Malaysian Water Resources Development Special Bulletinon Issues of Citizen's Health. Corporate Development, Department of Irrigation and Drainage,Kuala Lumpur, Malaysia, pp. 40-58.

[3] Iyagba, M. A., Adoki, A., and Sokari, T. G. 2008. Testing biological methods to treat rubbereffluent. African Journal of Agricultural Research, 3 (6), 448-454.

[4] Usa, I. 2007. Malaysia, Business and Investment Opportunities. Yearbook. InternationalBusiness Publications, USA, Washington DC 20003 USA-Malaysia. pp. 174-175.

[5] Mohammadi, M., Man, H. C., Hassan, M. A., and Yee, P. L. 2010. Treatment of wastewaterfrom rubber industry in Malaysia. African Journal of Biotechnology, 9 (38), 6233-6243.

[6] Khairuddin, M. I., and Abd Malek, A. 2002. Program Pencegahan Pencemaran DanPeningkatan Kualiti Air Sungai Langat. Proceeding Simposium Penyelidikan LembanganLangat 2001.

[7] Juahir, H., Zain, S. M., Yusoff, M. K., Tengku Hanidza, T. I., Mohd Armi, A. S., Toriman,M.E., and Mokhtar, M. 2011. Spatial water quality assessment of Langat River Basin(Malaysia) using environmetric techniques. Environmental Monitoring and Assessment, 173(1), 625-641.

[8] Lee, Y. H., Md, P. A., Chai, S. Y., Mazlin, M., and Rohani, A. 2006. Development ofpossible indicators for sewage pollution for the assessment of Langat river ecosystem health.Malaysia Journal of Analytical Sciences, 10 (1), 15-26.

[9] US EPA. 2000. Phytoremediation of Organics Action Team. Phytoremediation Site Profiles:Cantrall. Washington, DC.

[10] Muhiyuddin, W. M., and Rainis, R. 2002. Modeling landslide using GIS and RS: A casestudy of upper stream of Langat River Basin, Malaysia. In Proceedings of the internationalconference Environment: Ten Years After Rio (pp. 284-91).

[11] Kido, M., Yustiawati, Y., Syawal, M., Sulastri, S., Hosokawa, T., Tanaka, S., Saito, T.,Iwakuma, T., and Kurasaki, M. 2009. Comparison of general water quality of rivers inIndonesia and Japan. Journal Environmental Monitoring and Assessment, 156, 317-329.

[12] Bouwer, H. 2000. Integrated water management: emerging issues and challenges.Agricultural water management, 45 (3), 217-228. 
[13] Mazlin M., Shaharuddin I., Ahmad Fariz M. Abdul Hadi H. S. and Sarah A.A.G.A. (Eds).Lestari, UKM, Bangi, 183-189.

[14] Elfithri, R., Mokhtar, M., Harman Shah, A. H., and Idrus, S. 2002. Collaborative decision-making issues in sustainable water resources management: A case study on Langat basin. In 2002. Proceedings of the
International Conference on Environmental Management: Ten Years After Rio. Realising Agenda (Vol. 21, pp. 304-314).

[15] In Lee, Y.H., Abdullah, M.P., Chai, S.Y., Mokhtar, M. and Ahmad, R. 2006 Development of Possible Indicators for Sewage Pollution for The Assessment of Langat River Ecosystem Health. Malaysia Journal of Analytical Sciences, 10 (1), 15-26. 